\title{
Penerapan Augmented Reality sebagai Penampil Model 3D Rumah Berbasis Android pada The East View Residence
}

\author{
Roby Ibrahim Renata ${ }^{1}$, Jullend Gatc ${ }^{2)}$ \\ Sistem Informasi, Institut Teknologi dan Bisnis Kalbis, Jakarta \\ Jalan Pulomas Selatan Kav. 22, Jakarta 13210 \\ ${ }^{1)}$ Email: robyrenata@gmail.com \\ ${ }^{2)}$ Email: jullend.gatc@kalbis.ac.id
}

\begin{abstract}
The East View Residence is an existing home product in Kota Bekasi, with rapidly growing infrastructure development in Bekasi City makes The East View Residence needs to compete with the other competitors. Utilization of augmented reality technology in the field of business is not a new thing, especially in the field of marketing. This research aims to develop an Android-based augmented reality app that able to utilize brochures as a target image in displaying information related to home products offered by The East View Residence with Iterative Development approach. Based on the results and evaluation, this research succeeded in implementing Iterative Development research method in developing an application which is utilized for interesting and interactive marketing activities and giving added value to the brochure media itself.
\end{abstract}

Keywords: Android, augmented reality, iterative development, marketing

\begin{abstract}
Abstrak: The East View Residence merupakan sebuah produk rumah yang ada di Kota Bekasi, dengan terus berkembang pesatnya pembangunan infrastruktur di Kota Bekasimembuat The East View Residence harus mampu bersaing dengan kompetitor lainnya. Pemanfaatan teknologi augmented reality dalam bidang bisnis bukanlah hal yang baru, khususnya pada bidang pemasaran atau marketing. Penelitian ini bertujuan untuk mengembangkan sebuah aplikasi augmented reality berbasis Android yang mampu memanfaatkan brosur sebagai image target dalam menampilkan informasi terkait dengan produk rumah yang ditawarkan oleh The East View Residence dengan pendekatan Iterative Development. Berdasarkan hasil dan evaluasi, penelitian ini berhasil implementasikan metode penelitian Iterative Development dalam mengembangkan sebuah aplikasi yang dimanfaatkan untuk kegiatan marketing yang menarik dan interaktif serta memberikan nilai tambah untuk media brosur itu sendiri.
\end{abstract}

Kata kunci: Android, augmented reality, iterative development, pemasaran

\section{PENDAHULUAN}

Kota Bekasi, Jawa Barat merupakan salah satu kota yang saat ini menjadi incaran banyak pengembang properti untuk memenuhi kebutuhan hunian masyarakat kelas menengah. Hal tersebut salah satunya adalah didasari oleh jarak tempuh Bekasi menuju Jakarta yang kini cukup singkat dibandingkan dengan kota-kota penyangga lain [1].

Selain jarak tempuh, kota Bekasi juga saat ini sedang mengembangkan proyek pembangunan infrastruktur yang direncanakan dapat memberikan opsi tambahan bagi masyarakat yang bermukim di Bekasi dan bekerja di wilayah Jakarta. Infrastruktur tersebut adalah Tol Bekasi-Cawang-KampungMelayu (BECAKAYU) yang terintegrasi dengan jalur Light Rapid Transit (LRT). Dengan kehadiran Tol tersebut dalam waktu dekat, turut mendongkrak kenaikan harga properti [2].

The East View Residence merupakan salah satu produk properti pemukiman atau perumahan di daerah Bekasi Timur. Kualitas produk rumah dengan dua tipe, 84 dan 120 yang ditawarkan oleh The East View Residence dapat dikatakan relatif cukup baik, namun keterbatasan jumlah bagian marketing ditambah product knowledge yang dimiliki bagian marketing kurang memadai membuat penyampaian informasi kepada calon konsumen kurang sempurna. Selain itu penggunaan media maket, dan brosur dalam menampilkan objek produk rumah saat ini dianggap kurang efektif dan efisien. Calon konsumen tidak dapat mendapatkan informasi lebih detail ke bagian 
dalam rumah, warna dan tekstur dari bagian rumah, dan material yang digunakan. Selain faktor harga dan investasi, calon konsumen juga mempertimbangkan beberapa faktor lain seperti desain, lingkungan, aksesibilitas, infrastruktur, fasilitas umum, dan lokasi.

Penulis melakukan sebuah kuesioner tentang faktor yang mempengaruhi konsumen dalam memilih rumah kepada 50 responden secara acak dengan parameter umur 23-40 tahun dan yang telah memiliki penghasilan tetap.

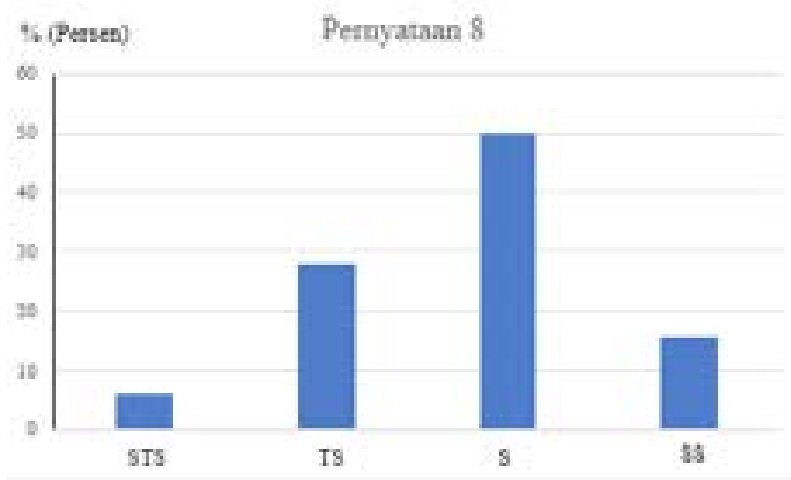

Gambar 1 grafik hasil kuesioner penggunaan brosur

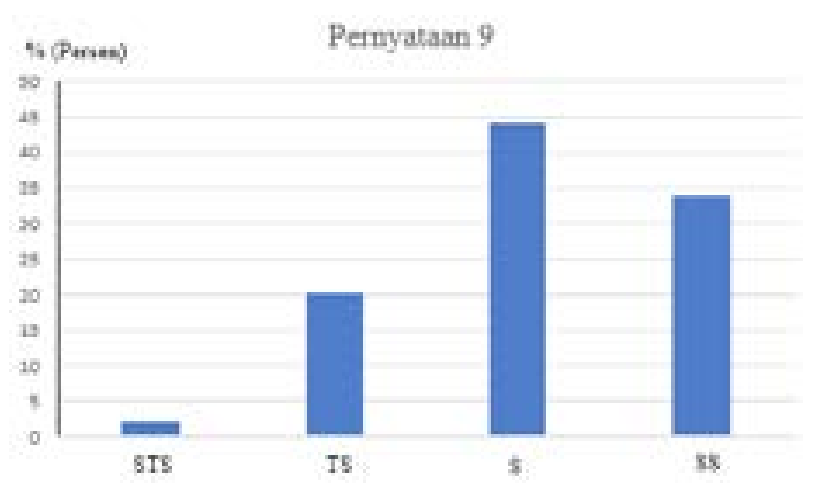

Gambar 2 grafik hasil kuesioner penggunaan maket

Dari Gambar 1 dan Gambar 2, dapat disimpulkan bahwa penggunaan brosur dan maket yang ada kini masih belum efektif dalam membantu calon konsumen untuk mendapatkan informasi yang diharapkan [3].

Saat ini, The East View Residence menggunakan beberapa media dalam proses pemasarannya yaitu brosur, dan maket. Pada brosur yang ada pada saat ini terdapat informasi produk rumah yang ditawarkan dengan informasi umum seperti denah produk rumah, peta lokasi, dan spesifikasi bangunan. Meskipun penggunaan media tersebut dapat dikatakan sudah cukup baik, namun penggunaan media tersebut masih bisa dimaksimalkan dengan implementasi sebuah teknologi, khususnya augmented reality.

Secara umum augmented reality yang merupakan salah satu teknologi yang menggabungkan dunia nyata dengan dunia virtual. Teknologi augmented reality sudah cukup dikenal oleh masyarakat sejak 2013 saat Google memperkenalkan sebuah konsep produknya, Google Glass [4]. Penerapan aplikasi yang menggunakan augmented reality sebagai teknologi dalam menampilkan pemodelan 3D di bidang bisnis sudah menjadi tren tersendiri saat ini, dan dianggap cukup interaktif dan efektif dalam menyampaikan informasi terkait.

Oleh karena itu pada penelitian ini, peneliti akan menerapkan augmented reality sebagai penampil model 3D produk rumah pada The East View Residence pada sebuah aplikasi berbasis mobile yang dapat menampilkan informasi yang tidak dapat ditampilkan oleh media sebelumnya yaitu brosur dan maket dengan lebih menarik dan interaktif. Platform yang akan digunakan adalah Android, pertimbangan memilih Android dibandingkan dengan platform lainnya seperti iOS dan Windows Phone adalah tercatat sejak 2016 Android mendominasi dan berada di urutan pertama sebagai salah satu platform mobile yang paling banyak digunakan dan terus berlanjut hingga saat ini [5]. Sedangkan pertimbangan peneliti memilih teknologi augmented reality dibandingkan dengan teknologi sejenis lainnya seperti, Virtual Reality (VR) atau Mixed Reality (MR) adalah peneliti beranggapan bahwa augmented reality lebih praktis karena cukup dengan menggunakan satu device mobile atau smartphone yang notabenenya adalah sebuah perangkat umum yang hampir setiap orang manfaatkan untuk berkomunikasi, sebagai alat yang akan digunakan dalam pengoperasian aplikasi [6].

Dengan hal tersebut maka didapatkan perumusan masalah yaitu, bagaimana membangun sebuah aplikasi yang memanfaatkan teknologi augmented reality berbasis Android yang mampu membantu proses marketing pada The East View Residence dalam memberikan informasi mengenai produk rumah yang ditawarkan secara kreatif dan interaktif kepada calon konsumen.

Tujuan dari penelitian ini adalah membuat sebuah aplikasi augmented reality berbasis Android yang menampilkan 3D modeling dari produk rumah The East View Residence. Untuk mencapai hasil akhir tersebut, diperlukan sebuah metode pengembangan aplikasi yang ideal. Pemilihan sebuah metode pengembangan aplikasi yang ideal akan berdampak kepada ketepatan hasil akhir yang diharapkan. Dengan hal tersebut, peneliti memanfaatkan sebuah metode pengembangan aplikasi Iterative Development yang memungkinkan peneliti untuk melibatkan pihak The East View Residence selama pengembangan aplikasi 
dalam hal kebutuhan fungsional ataupun nonfungsional.

\section{METODE PENELITIAN}

Terdapat metodologi pada penelitian ini yang meliputi: (1) Metode Wawancara (Interview); (2) Metode Observasi (Observation); dan (3) Metode pengembangan aplikasi (Iterative Development).

\section{A. Marketing}

Marketing atau pemasaran adalah sebuah perantara antara pelanggan atau konsumen dengan sebuah perusahaan. Bagian pemasaran harus memiliki kemampuan untuk memahami kebutuhan dari pelanggan, hal tersebut bertujuan untuk kepentingan tentang informasi pengembangan produk sesuai dengan kebutuhan dan spesifikasi pelanggan yang akan dipasarkan ke pelanggan yang telah diproses oleh perusahaan. Setelah sebuah produk berhasil dibuat, bagian pemasaran bertanggung jawab untuk berkomunikasi dengan konsumen terkait dengan informasi produk dan menunjukkan kepada konsumen bagaimana produk yang ditawarkan berbeda dengan produk yang ditawarkan kompetitor [7].

\section{Digital Marketing}

Digital Marketing merupakan sebuah kolaborasi hasil dari perkembangan teknologi IT dengan sebuah kegiatan pemasaran itu sendiri. Digital Marketing telah menjadi tren tersendiri bagi beberapa perusahaan sebagai cara untuk memasarkan produk atau jasa. Terdapat 2 kunci penting dalam sebuah Digital Marketing, yaitu Inovasi dan Digitalisasi.

\section{B. Augmented Reality}

Augmented Reality adalah sebuah proses menggabungkan pencitraan sebuah informasi yang berjalan secara real time dengan pandangan dunia nyata. Informasi yang dicitrakan dihasilkan dari proses yang berjalan lokal, sumber data, dan sumber data atau database yang tersimpan secara remote. Untuk dapat memanfaatkan teknologi augmented reality dibutuhkan beberapa teknologi pendukung yang meliputi: GPU (Graphical Processing Unit), difungsikan untuk menjalankan sebuah tampilan; Display/Alat Proyeksi, untuk mencitrakan gambar; Sensor, yang berupa kamera, posisi dunia nyata pada peta dalam bentuk 3D, sensor gerak, atau sensor mata; Sistem audio seperti mikrofon atau speaker, yang difungsikan untuk berkomunikasi; Identifikasi objek atau image target, yang digunakan sebagai pemicu bagi sensor untuk posisikan gambar virtual di atas atau dekat dengan objek tersebut; dan OS (Operating System). Dengan kata lain, augmented reality mampu menampilkan segala tipe informasi digital (video, foto, link, permainan, dan lainnya) di atas dunia nyata ketika dilihat melalui sebuah lensa kamera ataupun wearable device yang berhasil mendeteksi sebuah gambar berisi data yang telah diolah sebelumnya [9].

\section{Mobile Augmented Reality}

Mobile Augmented Reality atau MAR merupakan pengaplikasian teknologi augmented reality ke dalam sebuah platform mobile. Sistem dari MAR dapat dijelaskan dengan Gambar 1 [10]:

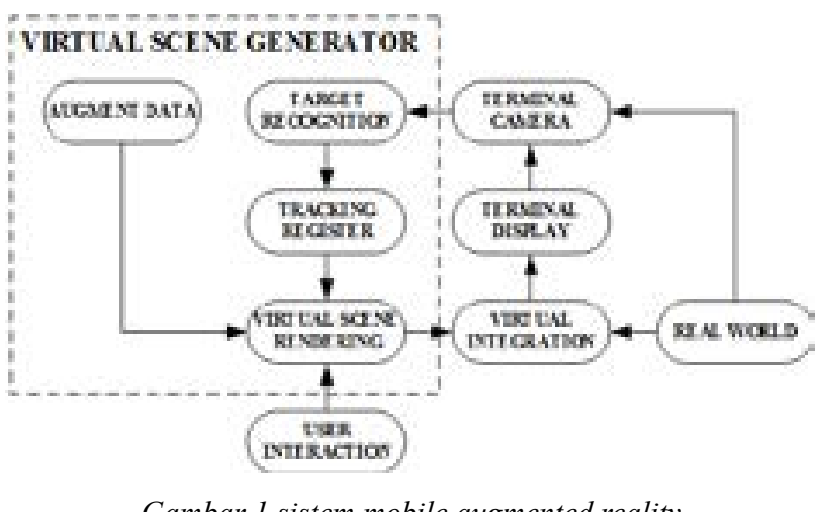

\section{Tracking Register Technology}

Tracking Register Technology atau teknologi pelacakan terdaftar merupakan sebuah metode yang memanfaatkan olah gambar dan teknologi visi komputer lainnya untuk melakukan perhitungan lokasi informasi terkait. Teknologi tersebut dapat dibagi menjadi 2 metode yaitu:

Marker Based Method

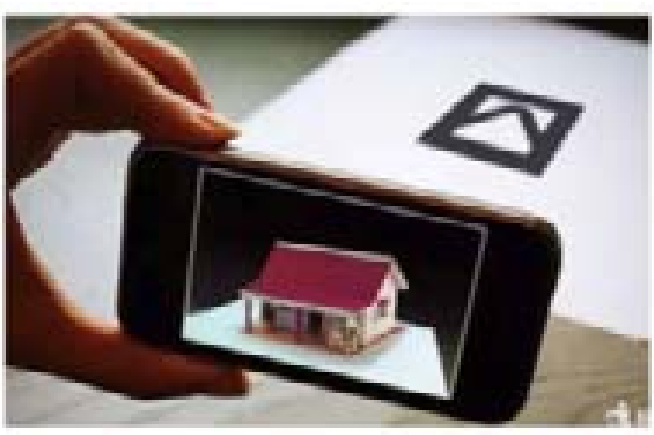

Gambar 2 marker based method [11]

Marker Based Method Gambar 2, menempatkan sebuah marker yang telah dikenali sebelumnya pada sebuah adegan di dunia nyata. Pengenalan marker tersebut dilakukan melalui edge detection dan template matching. Marker yang telah dikenali tersebut dapat digunakan untuk menghitung informasi matriks data spasial dari objek virtual di dunia nyata. 
Natural Feature Based Method

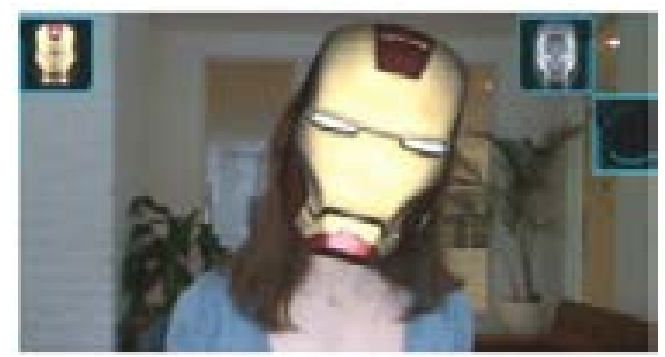

Gambar 3 natural featured based method

Natural Feature Based Method Gambar 3, merupakan sebuah metode Tracking Register Technology yang melakukan analisis video image di dunia nyata dan menghitung informasi matriks data spasial dari objek virtual di dunia nyata [11].

\section{Vuforia}

Vuforia merupakan sebuah Software Development Kit atau SDK untuk implementasi dari Mobile Augmented Reality atau MAR. Vuforia SDK menyediakan fungsi-fungsi yang dapat dimanfaatkan pengembang untuk mengembangkan aplikasi yang memanfaatkan teknologi augmented reality, fungsi tersebut meliputi Text Recognition, Cloud Recognition, Mutli-Targets, Frame Markers, Video Playback, Cylinder Recognition, Virtual Button Interactive, dan lainnya. Sebuah arsitektur Vuforia seperti pada Gambar 4:

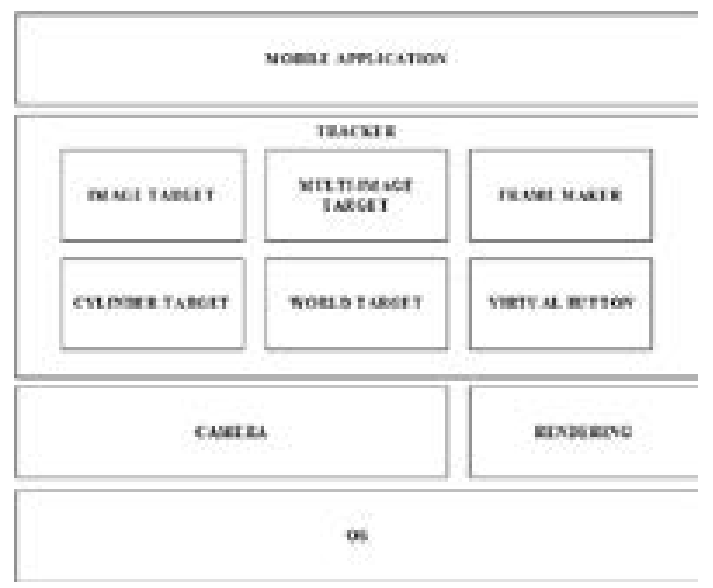

Gambar 4 arsitektur vuforia [12]

layer paling terendah adalah OS, dilanjutkan dengan layer Camera dan Rendering, lalu pada layer Tracker berisikan fungsi-fungsi yang terdapat pada Vuforia yang sudah disebutkan sebelumnya, dan di layer yang paling teratas adalah layer Mobile Application [12].

\section{Unity 3D}

Unity 3D merupakan sebuah software atau perangkat lunak yang umunya dimanfaatkan dalam pembuatan game khususnya game 3D, namun Unity 3D juga memberikan kemampuan kepada pengembang aplikasi untuk mengembangkan aplikasi berbagai platform dengan Unity 3D. Unity 3D juga dapat dimanfaatkan untuk membangun sebuah aplikasi yang memanfaatkan teknologi augmented reality [13].

Dengan memanfaatkan Unity 3D, pengembang dapat menguasai kompleksitas pengembangan aplikasi atau game dengan mudah. Kompleksitas tersebut meliputi pembuatan animasi, gerakan fisik, rendering, scripting, dan bahkan perancangan UI (User Interface) pada sebuah aplikasi atau game. Dengan kemudahan yang ditawarkan oleh Unity 3D, membuat waktu pengembangan dalam membangun sebuah aplikasi atau game menjadi lebih singkat dan ringkas [14].

\section{E. Iterative Development}

Iterative development merupakan salah satu bagian dari metode pengembangan yang bersifat use case driven. Berpusat pada arsitektur perangkat lunak, interaktif, dan applied Gambar 5.

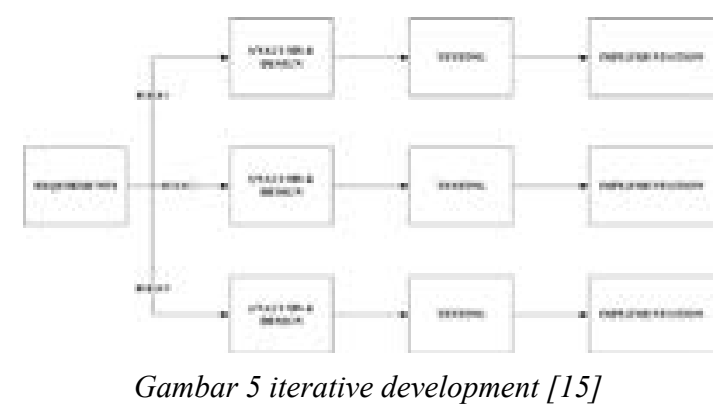

Sebuah metode Iterative Development memiliki tahapan-tahapan versi yang pada setiap tahapan versi memiliki proses-proses di dalamnya, secara umum proses-proses tersebut meliputi proses Design and Development, proses testing, proses Implementation. Banyaknya jumlah versi bergantung pada capaian target. Semakin tepat perancangan yang dilakukan, maka jumlah versi akan relatif lebih sedikit dan begitu juga sebaliknya, apabila terjadi cukup banyak perubahan yang dilakukan maka jumlah versi akan terus bertambah hingga mencapai tujuan yang telah disepakati sebelumnya.

Adapun yang membedakan proses-proses yang dilakukan antar setiap build-nya yaitu besarnya kepentingan yang ada proses satu dengan proses lainnya yaitu mengenai bobot dan waktu pelaksanaan dari setiap prosesnya, dan dari keseluruhan proses yang ada terbagi menjadi empat fase yaitu:

Fase Inception, merupakan tahapan paling awal yang dilakukan dalam pengembangan, 
aktivitas yang dilakukan dalam tahapan ini meliputi aktivitas penilaian yang bertujuan untuk mencapai kesepakatan dengan pihak terkait khususnya dengan pihak The East View Residence, kesepakatan yang dibuat sehubungan dengan tujuan, dan capaian akhir dari penelitian yang dilakukan.

Fase Elaboration, setelah melewati fase Inception, dilanjutkan dengan fase Elaboration yang bertujun untuk mendapatkan gambaran umum mengenai kebutuhan, persyaratan, dan fungsifungsi utama atau fitur dari aplikasi yang akan dikembangkan dengan cara melakukan wawancara langsung dengan pihak dari The East View Residence, studi literatur, dan kuesioner yang telah dijelaskan pada bab sebelumnya. Hal tersebut dilakukan untuk mengetahui secara lebih mendalam mengenai risikorisiko dari pengembangan yang akan dilakukan, baik meliputi risiko arsitektur aplikasi, perencanaan, ataupun implementasi. Pada tahap ini telah dimulai rancangan pengembangan aplikasi secara iterative dengan melakukan proses Business Modelling, Requirments, Analysis, dan Design tahap awal.

Fase Construction, merupakan tahapan dalam pembangunan aplikasi sampai dengan aplikasi dapat digunakan atau mencapai versi akhir. Fase Construction menitik beratkan pada penentuan tingkat prioritas kebutuhan atau persyaratan, melengkapi spesifikasi, analisis lebih mendalam, desain dari solusi permasalahan yang memenuhi kebutuhan atau persyaratan, coding, dan pengujian aplikasi. Jika dimungkinkan, versi awal dari aplikasi atau prototype dari aplikasi sudah dapat diuji coba untuk mendapatkan masukan mengenai pengembangan aplikasi ke depannya.

Fase Transition, difokuskan agar aplikasi yang sudah selesai dikembangkan dapat tersampaikan kepada user atau pengguna. Aplikasi akan mulai diuji, pengujian dilakukan oleh pihak-pihak terkait yang pada penelitian ini merupakan pihak marketing dari The East View Residence, serta dosen pembimbing skripsi. Serta kegiatan seperti pelatihan untuk penggunaan aplikasi juga dilakukan pada fase ini lihat Gambar 6.

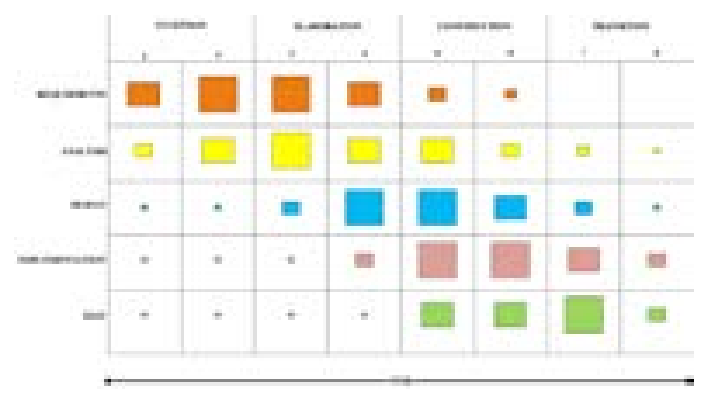

Gambar 6 fase iterative development [15]
Metode Iterative Development memiliki lima alur kerja yang meliputi Requirments, Analysis, Design, Implementation, dan Test. Terdapat juga empat fase yang membagi setiap workflow yang ada, fase tersebut meliputi fase Inception, fase Elaboration, fase Construction, dan fase Transition. Besaran bobot dan waktu dari pengerjaan dari setiap workflow digambarkan dengan bentuk persegi. Besaran bentuk persegi mengikuti besaran waktu dan bobot yang dilakukan pada workflow dan fase tertentu. Sedangkan angka yang ada menunjukkan jumlah iterasi yang terjadi pada setiap fasenya. Gambar dan penjelasan tersebut tidak bersifat mutlak, karena kasus dan kebutuhan dari setiap permasalahan akan berbeda [15].

\section{F. Penelitian Terdahulu}

Penelitian sejenis ini telah dilakukan sebelumnya, sebab penelitian terdahulu dirasa sangat penting dalam sebuah penelitian yang akan dilakukan. Beberapa penelitian terdahulu yang mendasari penelitian ini adalah Implementasi Augmented Reality (AR) pada Fosil Purbakala di Museum Geologi Bandung. Tujuan dari penelitian ini adalah memberikan informasi yang menarik dan interaktif dari bagian-bagian kerangka fosil yang tidak utuh dengan memanfaatkan ponsel untuk memenuhi kekurangan kerangka fosil yang tidak utuh tersebut dan dicitrakan melalui proyeksi 3D ataupun video dengan memanfaatkan teknologi augmented reality. Aplikasi tersebut mampu membantu pengguna dalam menyampaikan informasi yang dibutuhkan, selain itu aplikasi mampu mengurangi beban biaya pembuatan fosil replikasi [16].

Selain itu implementasi teknologi di bidang bisnis atau industri sudah dilakukan oleh salah satu perusahaan furnitur asal Swedia, IKEA. IKEA sejak tahun 2012 telah mengembangkan sebuah aplikasi mobile yang memanfaatkan teknologi augmented reality untuk melakukan visualisasi terhadap produknya yang dapat di proyeksikan ke dunia nyata secara virtual. Aplikasi tersebut mampu meningkatkan fungsi dari brosur yang dimiliki serta meningkatkan minat dari calon konsumen terhadap produk dan fitur yang ditawarkan oleh IKEA [17].

\section{HASIL DAN PEMBAHASAN}

\section{A. Fase Inception}

Didapatkan beberapa kebutuhan fungsional yang dibutuhkan pada fase ini dan tercatat pada dokumen BRD (Business Requirments Document). 
Dan pada fase ini dilakukan perancangan awal dari pengembangan aplikasi di iterasi pertama ini. Aplikasi memiliki kemampuan untuk aktifkan sensor kamera pada perangkat Android untuk melakukan scan image target yang sudah ditentukan sebelumnya, apabila berhasil melakukan scan image target maka akan tampil pada layar perangkat Android sebuah objek 3D berbentuk bola. Flow chart Gambar 7.

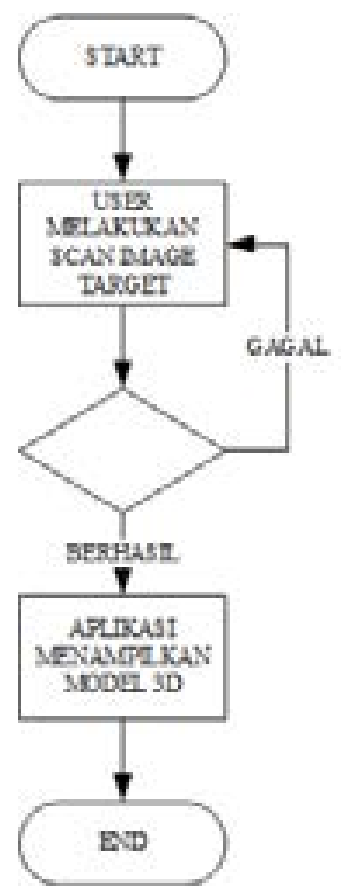

Gambar 7 flowchart diagram aplikasi $i$

Dan ditetapkan untuk image target yang digunakan Gambar 8:

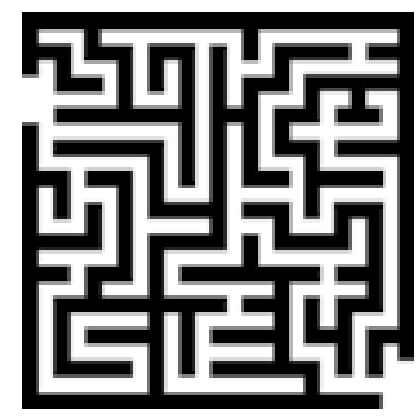

Gambar 8 image target trigger 1

Image target yang sudah ditentukan tersebut diimplementasikan ke dalam software Unity untuk menjadi trigger dalam menampilkan objek 3D bola, Gambar 9.

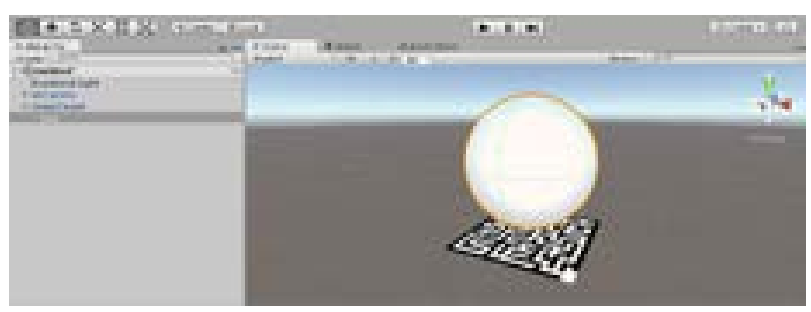

Gambar 9 objek bola pada objek image target
Lalu aplikasi dibangun atau build melalui Unity Editor dengan output berupa APK yang dapat diinstall pada perangkat Android.

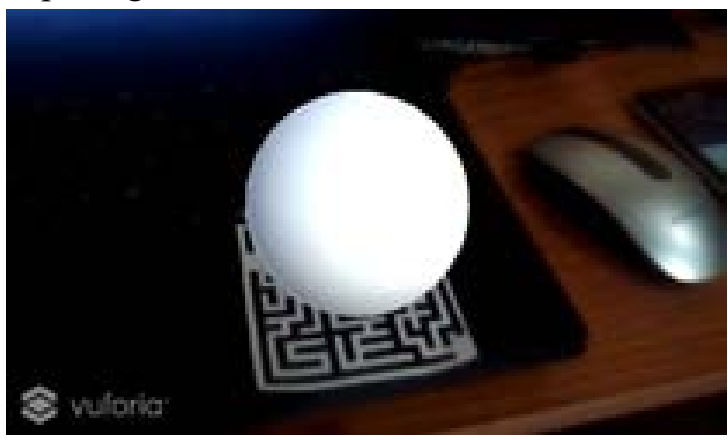

Gambar 10 aplikasi versi 1.0

Aplikasi berhasil menampilkan objek bola Gambar 10, seperti yang diharapkan ketika kamera berhasil melakukan scan image target yang telah ditentukan.

\section{B. Fase Elaboration}

Setelah didapatkan kembali kebutuhan fungsional yang baru dan tercatat pada dokumen BRD, pada fase ini penelitian berinisiasi untuk fokuskan kegiatan pemodelan 3D rumah. Di awali dengan melakukan marking awal dari data CAD rumah The East View Residence dengan memanfaatkan software Sketchup, seperti pada Gambar 11.

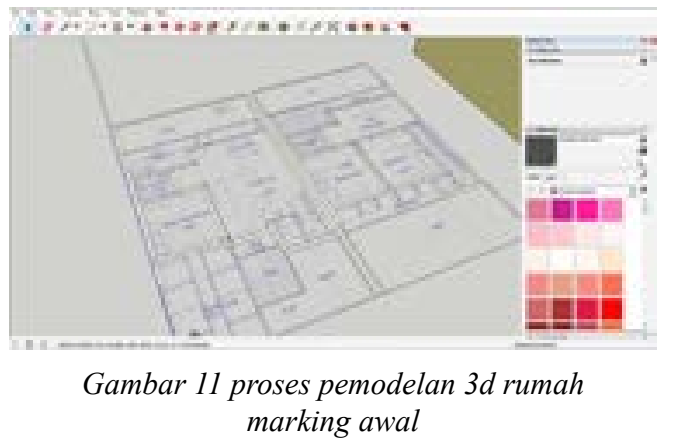

Dilanjutkan dengan penarikan tembok yang tingginya disesuaikan dengan data CAD terkait, seperti pada Gambar 12.

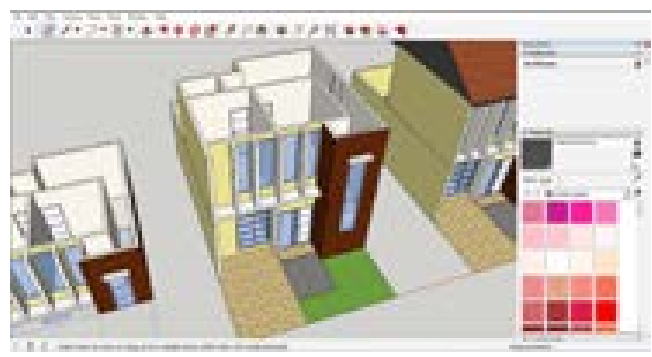

Gambar 12 proses pemodelan $3 d$ rumah

Lalu dilakukan pengujian terhadap hasil desain rumah yang dilakukan oleh peneliti dengan pihak The East View Residence dengan perhitungan parameter pengujian yang meliputi ukuran bangunan, bentuk 
bangunan, dan warna bangunan. Dan semua hasil model 3D yang telah dibuat dapat diterima.

\section{Fase Construction}

Kembali didapatkan kebutuhan fungsional yang dibutuhkan dalam pengembangan aplikasi yang tercatat pada dokumen BRD. Pada fase ini peneliti mulai merancang desain image target baru yang berupa brosur Gambar 13, dan merancang UI (User Interface) Gambar 14 serta struktur navigasi aplikasi, Gambar 15.

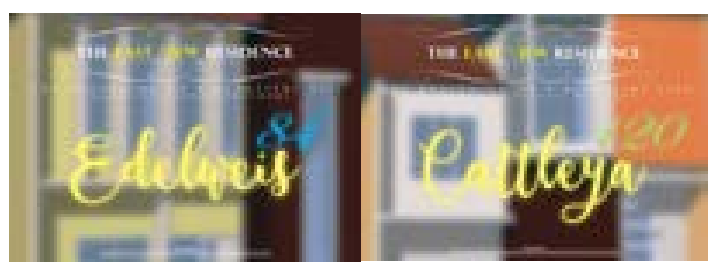

Gambar 13 Desain brosur baru

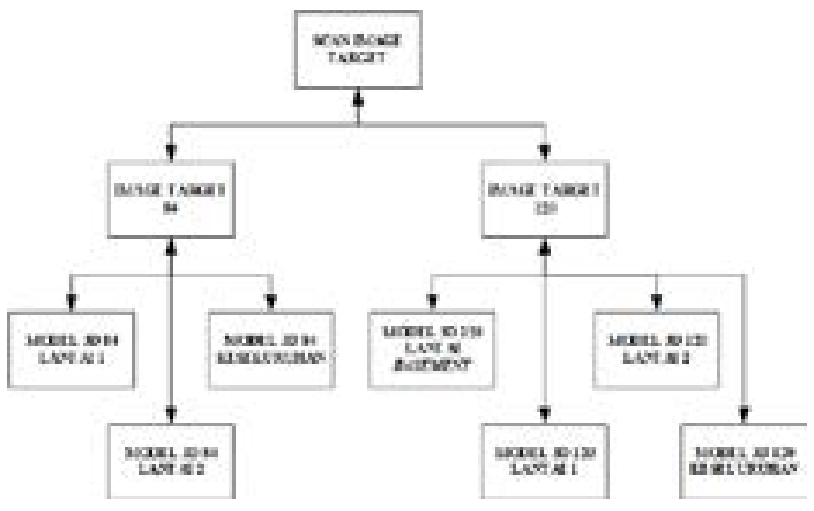

Gambar 14 struktur navigasi scene AR camera

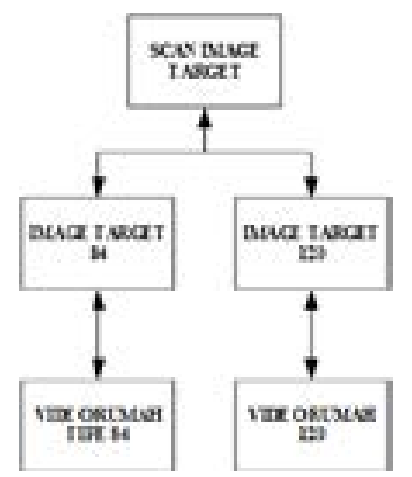

Gambar 15 struktur navigasi scene video

Hasil rancangan tersebut diimplementasikan ke dalam software Unity dan diintegrasikan antar scene satu dengan yang lainnya Gambar 16 .

Lalu didapatkan hasil akhir yang diimplementasikan dengan perangkat Android, Gambar 17.

Kembali dilakukan testing atau pengujian oleh pihak The East View Residence dengan parameter terkait dengan scene yang diuji. Untuk scene $A R$ Camera memiliki parameter image target terkait

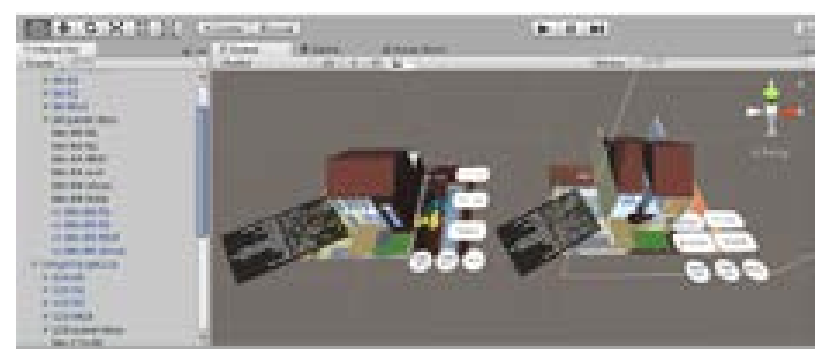

Gambar 16 implementasi scene AR camera

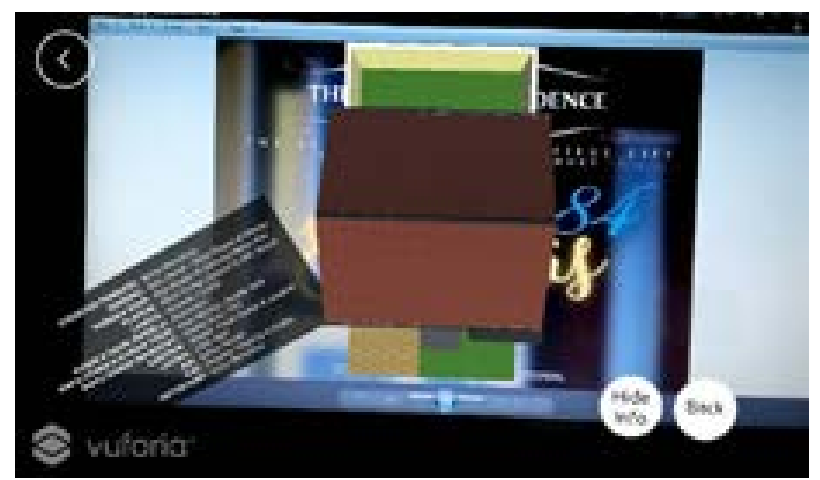

Gambar 17 hasil scan image target scene AR camera

dapat menampilkan objek 3D terkait dan objek informasi spesifikasi rumah. Sedangkan untuk scene Video memiliki parameter image target terkait dapat menampilkan video representasi kondisi rumah terisi.

\section{Fase Transition}

Pada fase ini, walaupun didapatkan kembali kebutuhan fungsional yang dibutuhkan untuk pengembangan aplikasi, namun terhitung jumlah kebutuhan baru semakin berkurang jika dibandingkan pada fase sebelumnya. Pada fase ini selain memenuhi kebutuhan yang baru, peneliti juga berinisiasi untuk memenuhi kebutuhan fungsional yang belum terpenuhi sebelumnya dan melakukan optimalisasi terkait dengan aplikasi. Pada fase ini peneliti merancang sebuah struktur navigasi untuk penambahan scene yaitu scene Manual, Gambar 18 .

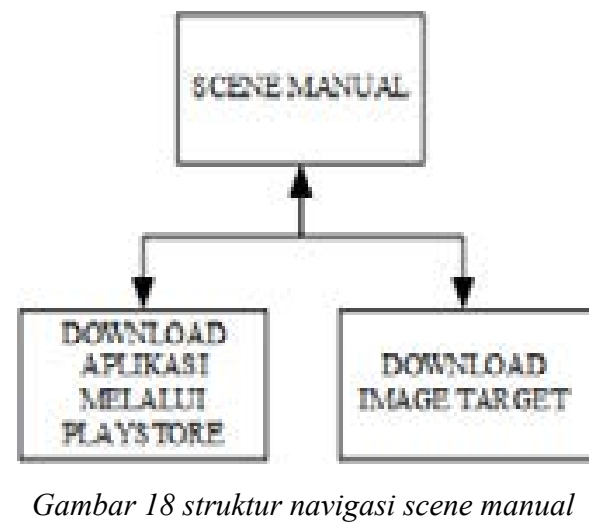

Dari hasil rancangan tersebut diimplementasikan ke dalam software Unity, Gambar 19. 
Lalu kembali dilakukan implementasi yang dilakukan pada perangkat Android untuk menguji fitur download image target yang sudah di-host ke dalam Google Drive dan juga link download aplikasi pada Google Playstore, Gambar 20.

Peneliti juga mengimplementasikan struktur navigasi scene menu utama atau main menu yang sudah dirancang pada fase sebelumnya, Gambar 21.

Lalu kembali diimplementasikan ke dalam perangkat Android agar dapat dilakukan pengujian, Gambar 22.

Dilakukan kembali pengujian untuk setiap fungsi atau fitur yang ada pada scene manual dan scene main menu. Untuk scene manual memiliki parameter icon download image target dapat menuju link host Google Drive dan icon download aplikasi dapat menuju Google Playstore untuk download aplikasi. Sedangkan parameter scene main menu

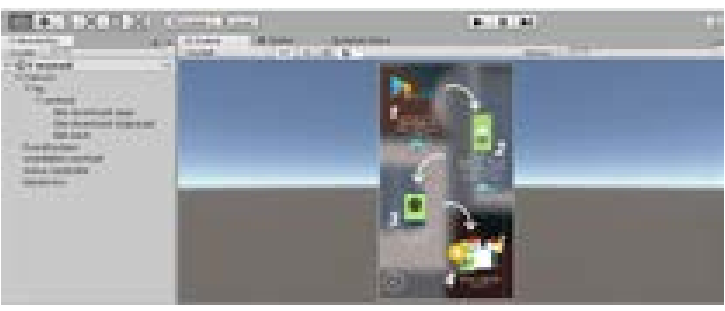

Gambar 19 implementasi scene manual

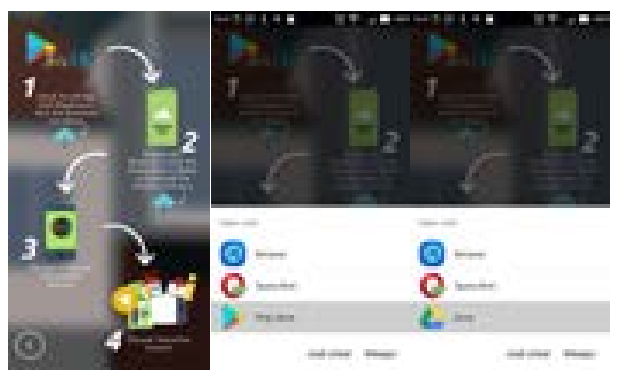

Gambar 20 implementasi scene manual pada perangkat android

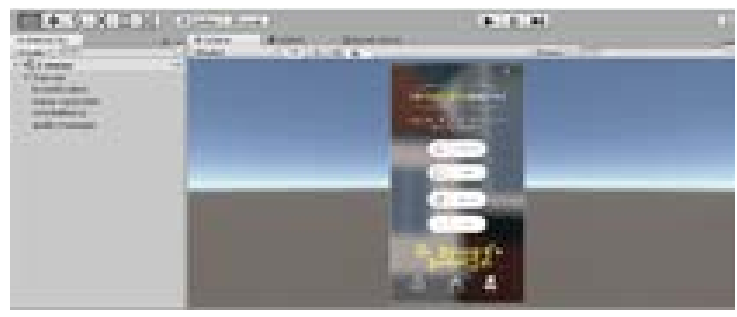

Gambar 21 implementasi scene main menu

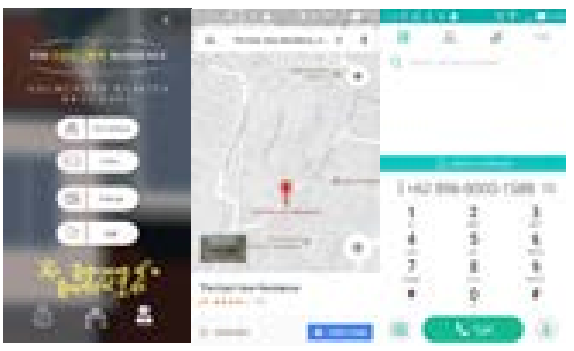

Gambar 22 implementasi scene main menu pada perangkat android adalah selain icon location dapat membuka aplikasi penyedia layanan peta yang langsung menunjukkan lokasi dari The East View Residence dan icon contact dapat membuka aplikasi penyedia layanan telepon yang lansung menghubungi kontak terkait. Berdasarkan parameter tersebut pengujian diterima oleh pihak The East View Residence.

\section{SIMPULAN}

Berdasarkan hasil keseluruhan penelitian dapat diketahui bahwa, hasil akhir penelitian adalah produk aplikasi The East View Residence Augmented Reality (TEVRAR) berbasis Android yang mampu menampilkan model 3D dan informasi terkait dari produk rumah The East View Residence yang memanfaatkan brosur sebagai Image Target. Setiap fitur, interface, tombol, dan kontrol di dalam aplikasi dapat berjalan dengan baik.

Selain itu dengan memanfaatkan metode Iterative Development memungkinkan peneliti untuk melakukan kegiatan Implementation dan juga Test dalam fase Inception secara bersamaan dengan kegiatan lainnya. Pada fase Elaboration, memiliki bobot besar pada kegiatan Requirments dan juga Analysis and Design, sedangkan pada kegiatan Implentation, dan Test juga dirasakan bobot pengerjaan kegiatan yang semakin meningkat intensitasnya. Dilanjutkan dengan fase Construction, pada fase ini bobot kegiatan Requirments, dan Analysis and Design sudah mulai berkurang intensitasnya, namun pada kegiatan Implementation, dan Test memiliki intensitas bobot kegiatan yang cukup tinggi. Diakhiri dengan fase Transition, kegiatan Requirments dan juga Analysis and Design dapat dikatakan hampir tidak ada kegiatan, namun pada kegiatan Implementation, dan juga Test dirasakan berada pada puncak intensitas bobot kegiatan.

Dari hasil akhir penelitian ini juga dapat disimpulkan bahwa pemanfaatan teknologi Augmented Reality dapat diimplementasikan ke dalam sebuah proses bisnis, khususnya dengan hasil akhir yang kreatif dan interaktif. Hal tersebut menunjukkan bahwa teknologi Augmented Reality juga memiliki potensi besar untuk diimplementasikan ke dalam proses bisnis lain.

\section{DAFTAR RUJUKAN}

[1] H. Kurniawan, "Bisnis Properti di Bekasi Kian Menjanjikan,” 2017. [Online]. Available: https://ekbis. sindonews.com/read/1205543/179/bisnis-properti-di- 
bekasi-kian-menjanjikan-1494920674. [Accessed: 01Jan-2017].

[2] F. Azkia, "Bekasi Terus 'Dijejali' Infrastruktur Teranyar,” 2017. [Online]. Available: https://www. rumah.com/berita-properti/2017/4/151516/bekasiterus-dijejali-infrastruktur-teranyar. [Accessed: 01-Jan2017].

[3] R. Renata, "Hasil Kuesioner Faktor yang Mempengaruhi Konsumen dalam Membeli Rumah (Responses)." 2017.

[4] H. Ling, "Augmented Reality in Reality," IEEE Multimed., vol. 24, no. 3, pp. 10-15, 2017.

[5] J. Vincent, "99.6 percent of new smartphones run Android or iOS," 2017. [Online]. Available: https:// www.theverge.com/2017/2/16/14634656/android-iosmarket-share-blackberry-2016. [Accessed: 01-Jan2017].

[6] A. Dachis, "What's the Difference Between AR, VR, and MR?," 2017. [Online]. Available: https://next. reality.news/news/whats-difference-between-ar-vrand-mr-0171163/. [Accessed: 01-Jan-2017].

[7] K. Moore and N. Pareek, MARKETING THE BASICS. London: Routledge, 2006.

[8] P. J. M. A. J. M. Malar, "Innovative Digital Marketing Trends 2016,” pp. 4550-4556, 2016.

[9] J. Peddie, Augmented Reality: Where we all live, vol. October 20, no. 103. Tiburon: Springer, 2017.

[10] Di. Chatzopoulos, C. Bermejo, Z. Huang, and P. Hui, "Mobile Augmented Reality Survey: From Where We Are to Where We Go," IEEE Access, vol. 5, no. c, pp. 6917-6950, 2017.
[11] P. Fuguo and J. Zhai, "A mobile augmented reality system for exhibition hall based on Vuforia," 2017 2nd Int. Conf. Image, Vis. Comput. ICIVC 2017, pp. 1049-1052, 2017.

[12] C. Xiao and Z. Lifeng, "Implementation of mobile augmented reality based on Vuforia and Rawajali," 2014 IEEE 5th Int. Conf. Softw. Eng. Serv. Sci., pp. 912-915, 2014.

[13] Unity, "Unity Documentation," 2017. [Online]. Available: https://docs.unity3d.com/Manual/index. html. [Accessed: 10-Jan-2018].

[14] S. Jackson, Unity 3D UI Essentials. Birmingham: Packt Publishing Ltd., 2015.

[15] J. W. Satzinger, R. B. Jackson, S. D. Burd, and R. Jackson, Systems Analysis and Design in a Changing World. Boston, 2016.

[16] Y. saputra, aprillio, "Implementasi augmented reality (ar) pada fosil purbakala museum geologi bandung Teknik Informatika - Universitas Komputer Indonesia Jurnal Ilmiah Komputer dan Informatika ( KOMPUTA )," Implementasi Augment. Real. pada fosil purbakala museum Geol. bandung Tek. Inform. - Univ. Komput. Indones. J. Ilm. Komput. dan Inform. ( KOMPUTA), pp. 1-8, 2014.

[17] A. Pardes, "IKEA'S NEW APP FLAUNTS WHAT YOU'LL LOVE MOST ABOUT AR,” 2017. [Online]. Available: https://www.wired.com/story/ikea-place-arkit-augmented-reality/. 